\title{
火災統計データに基づく火災拡大危険評価法 \\ A STUDY ON RISK OF FIRE SPREAD BASED ON THE FIRE STATISTICS DATA
}

\author{
佐 藤 博臣, 村井裕 樹**, 志田弘二***, 栗 岡 均**** \\ Hiroomi SATOH, Hiroki MURAI, Kouji SHIDA \\ and Hitoshi KURIOKA
}

It is taken up fire damage area as a parameter about fire damage from the fire statistics data, grasped the distribution characteristic, and analyzed the influence which factors, such as a situation of the building management, the equipment for fire fighting, etc., have on fire damage area expansion of a fire building for several building use. It could use for evaluation of the item which influences expansion and control of a fire, and the fire damage deterrence effects, such as evaluation of the size of the influence, and equipment or the regulation effect by the statute, and for the fire risk assessment of a building further.

The size of the item which influences expansion and control of a fire, and influence was analyzed by comparing the cumulative frequency distribution of the fire damage area created according to the situation of fire prevention building classification, structure, management, equipment, etc. using the coefficient of regression. If the result of this paper is examined still in detail, it may be applicable to evaluation of the fire damage deterrence effects, such as equipment, or the regulation, and also the fire risk assessment of a building.

Keywords : $\quad$ Fire, Statistics data, Fire damage area, Logarithm frequency distribution, Fire risk 火災、統計デー夕、焼損面積、対数度数分布、火災リスク

\section{1 背景・目的}

火災損害の大きさは、建築物の用途（防火対象物区分など）や使 われ方、防火対策が複雑に影響する。これに対し、火炎統計に基づ き防火対象物の火災危険性に応じた合理的な防火安全対策手法の構 築にかかわる、日常管理状況や消防用設備の設置状況などが奏功す る初期火災の火災シナリオモデルの確立を目指した研究は多くなく、 関沢らの火災統計分析 1) 2)、野崎らの研究 9) 10) 12)に留まり、また 超過確率分布を用いたものが多く、より多くの人が活用するには専 門性が高い。本研究では、貴重な過去の火災事故データ群から、個々 の防火対策が有する損害抑止効果を理解しやすい形で定量化するこ とを目的としている。

具体的には、統計データとして蓄積されたデータの中から、火災 損害に関するパラメータとして焼損床面積をとりあげ、その分布特 性を把握し、建物用途ごとに、火災前の日常管理や消防用設備等の 整備状況が、火元建物の焼損床面積㹡大に対して奏効しているか不 奏効かを分析し、有意な結果が出るのか、その結果が工学的に利用 できるのかを把握することである。なお、その過程で分析手段とし て焼損床面積に対する回㷌式を使用しているが、既往の火災事例に おける損害の把握のための焼損床面積の平均値や最大值を推計する ことは目的としていない。これにより、火災の桩大や抑制に影響す
る項目とその影響の大きさの評価、設備等の火災損害抑止効果や法 令による規制効果の評価に利用できるものと考えた。

\section{2 使用データと分析方法}

本研究では、火災報告注 1) に基づく火災データを使用した。対象 は、1996 年から 2002 年の 7 年間注2) の、防火対象物に関する火元 建物データである。抽出条件と抽出理由及び分析対象の火災件数を 図 1 に示す。

\begin{tabular}{|c|c|}
\hline 抽出に用いた条件 & 火災件数 \\
\hline 全火災 (1996年～2002年) & 428826 \\
\hline $\begin{array}{l}\text { 建物火災(火災種別) } \\
\text { :本研究では建物火災を対象とするため) }\end{array}$ & 237469 \\
\hline $\begin{array}{l}\text { 爆発でない(爆発現象の状況) } \\
\text { :燒損床面積を分析対象とするため }\end{array}$ & 236563 \\
\hline $\begin{array}{l}\text { 防火対象物火災 } \\
\text { :本研究では防火対象物を対象とするため }\end{array}$ & 105014 \\
\hline $\begin{array}{l}\text { 建築桙造の記述あり } \\
\text { :耐火性の差異を明確にするため }\end{array}$ & 97752 \\
\hline $\begin{array}{l}\text { 建築面積 }>0 \text { 、延面積 }>0 \\
\text { :焼損床面積が必ず } 0 \mathrm{~m}^{2} \text { となるため }\end{array}$ & 97450 \\
\hline $\begin{array}{l}\text { 出火原因が放火・放火の疑い以外 } \\
\text { :出火原因として特殊なため }\end{array}$ & 74828 \\
\hline
\end{tabular}

图 1 分析対象の抽出象件注3
*イー・アール・エス 博士 (工学)

** 日本大学大学院理工学研究科 研究生 - 博士 (工学)

*** 名古屋市立大学大学院芸術工学研究科教授. 工博

**** 鹿島技術研究所 博士 (工学)
Engineering \& Risk Services Corp., Dr. Eng.

Research Student, Nihon Univ., Dr. Eng.

Prof., Nagoya City Univ., Dr. Eng.

Kajima Technical Research Institute, Kajima Corp., Dr. Eng. 
災害の頻度と規模の特徴を示す場合、超過確率分布で論ずること が多く見られるが、火災は他の自然災害に比べて、防火区画による 最大焼損床面積の制限、日常管理や消火活動など人的な影響も強く、 被害にある程度の上限があり、従来、超過確率分布で直線性を有し ていた他の自然災害とは性格を異にすると考えられる。そのため、 本論文では、その工学的な意味の把握のため、累積相対度数分布で 解析を進めることにし、さらにその意味するところを簡易に表現す るため、累積相対度数の対数回帰注 4$)$ により代表值の有効性を提示 した。

\section{3 用途別出火率と焼損床面積の㑯向}

分析対象とした防火対象物の出火率（1000 防火対象物あたり）、 火災件数、焼損床面積の基本統計量を表 1 に示す。

-火災件数：「共同住宅等」（25243 件）が非常に多く、次いで「特 定複合用途」(12526 件)、「工場・作業場（以下、「工場等」と略す）」 (12269 件) が多い。防火対象物全体に占める割合は、「共同住宅等」 で約 34\%、これら 3 防火対象物で約 67\%である。一方、「地下街」 (1〜7 件)、「文化財」(10 件)、「航空機格納庫」（16 件）が少ない。 - 焼損床面積 : 平均値は、「事業場 (その他)」 $\left(96.5 \mathrm{~m}^{2}\right)$ 、「倉庫」 $(94.0$ $\left.\mathrm{m}^{2}\right)$ 、「工場等」 $\left(89.8 \mathrm{~m}^{2}\right)$ 、「神社・寺院等」 $\left(80.3 \mathrm{~m}^{2}\right)$ が大きい。最 大值は、「工場等」 $\left(21370.0 \mathrm{~m}^{2}\right)$ が非常に大きく、次いで「倉庫」(8296.6 $\left.\mathrm{m}^{2}\right)$ 、「事業場 (その他)」(4352.0 $\left.\mathrm{m}^{2}\right)$ 、「物品販売店舗等」 $(4025.0$ $\mathrm{m}^{2}$ ) である。

以上の結果より、出火率、火災件数、焼損床面積の大きさなどの 特徴を踏まえ、また社会的にも主要な用途であることも考虑し、以 下では、「事業場 (事務所)（以下、「事務所」と略す）「共同住宅等」 「物品販売店舗等」「病院等」「工場等」を取上げ詳細に分析を行う。

\section{4 累積相対度数分布による建物用途ごとの狫損床面㮴の㑯向}

焼損床面積の分布特性を分析するため、焼損床面積に関する火災

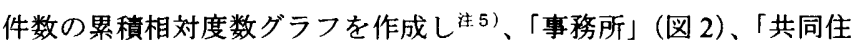
宅等」(図 3)、「物品販売店舗等」(図 4)、「病院等」(図 5)、「工場 等」(図 6) に建築構造ごと示す。火災報告では建築構造は 6 分類で あるが建築材料の耐火性に着目し表 2 に示す 2 分類で整理する注6)。

\section{1 建物用途ごとの分析}

（1）事務所（図 2)

建築構造による焼損床面積の分布特性に大きな差があり、建物構 造の耐火性能が高い場合、大規模火災になりにくい傾向が顕著であ る。「非木質系建築物（以下「非木質系」と略す）」では、焼損床面 積 $1 \mathrm{~m}^{2}$ 以下が約 $70 \% 、 10 \mathrm{~m}^{2}$ 以下が約 $80 \%$ となり、100 $\mathrm{m}^{2}$ 以下が約 95\%である。「木質系建築物（以下「木質系」と略す）」では、1 $\mathrm{m}^{2}$ 以下が約 $40 \% 、 10 \mathrm{~m}^{2}$ 以下が約 $55 \% 、 100 \mathrm{~m}^{2}$ 以下が約 $85 \%$ である。1 $\mathrm{m}^{2}$ 以下の累積相対度数は、「木質系」「非木質系」ともに「工場等」 とほぼ同じであるが、焼損床面積の拡大に従う累積相対度数の上昇 度合は「事務所」のほうが傾きが大きく、焼損床面積が拡大しにく い。これは、「事務所」には、防火区画を構成する以外にも、雑壁や 鋼製家具など火災拡大に対して一定の抑制効果を持つものが多いこ とも理由と考えられる。

（2）共同住宅等（図 3)

建筑構造による焼損床面積の分布特性の差が他の防火対象物に比

\section{表 1 防火対象物の基本統社年}

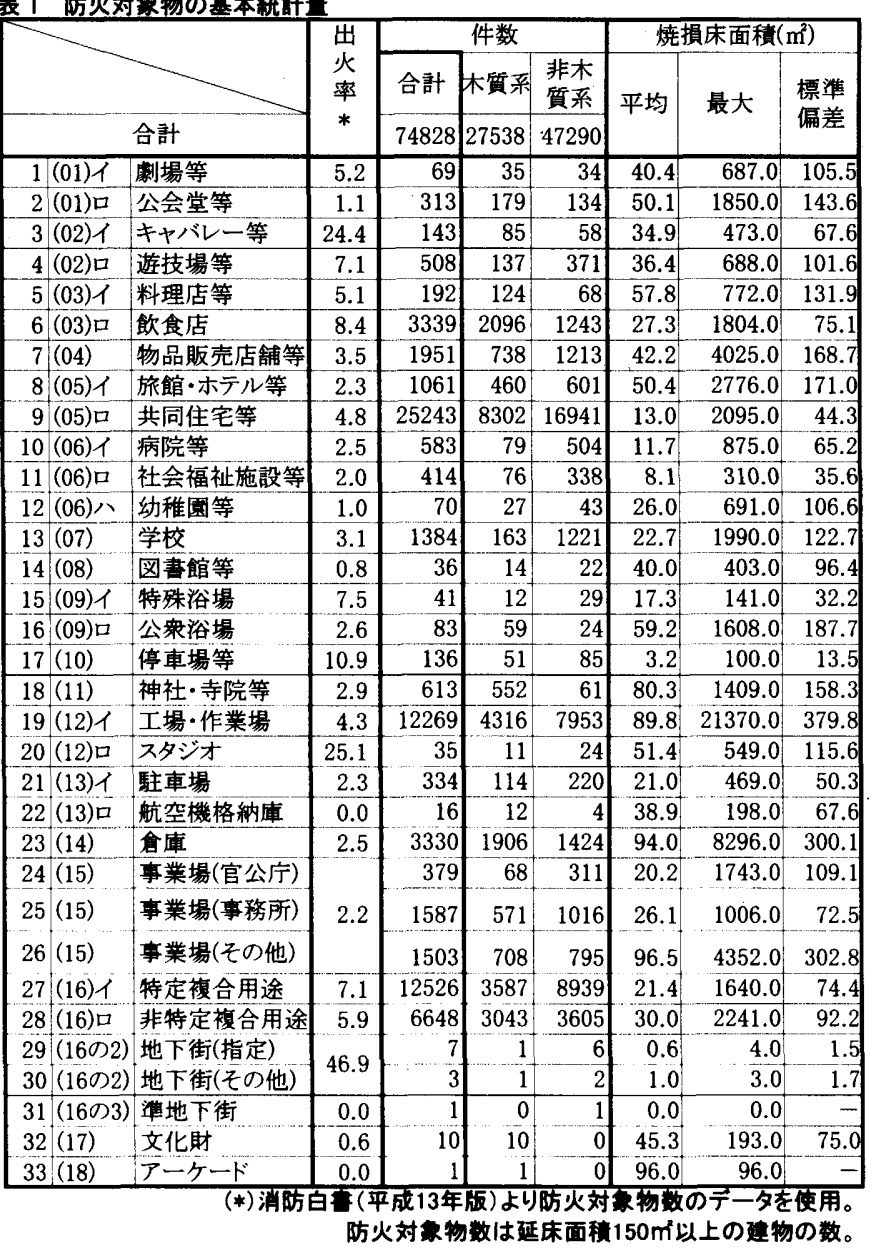

(出火革 $)=($ 出火件数 $) /($ 昉火対事物数)による。(建物1000件あたり

\begin{tabular}{|c|c|c|}
\hline & 本研究での分類 & 火災報告での分類 \\
\hline \multirow{5}{*}{$\begin{array}{l}\text { 建 } \\
\text { 築 } \\
\text { 構 } \\
\text { 造 }\end{array}$} & \multirow{3}{*}{ 木質系建築物 } & 木造建築物 \\
\hline & & 防火構造建築物 \\
\hline & & 準耐火建築物(木造) \\
\hline & \multirow{2}{*}{ 非木質系建築物 } & 準耐火建築物(非木造) \\
\hline & & 耐火建築物 \\
\hline
\end{tabular}

べて少ない。「非木質系」では、焼損床面積 $1 \mathrm{~m}^{2}$ 以下が約 75\%、10 $\mathrm{m}^{2}$ 以下が約 $80 \%$ と差が少ない。また、焼損床面積約 $100 \mathrm{~m}^{2}$ で約 $100 \%$ に到達しており、火炎が発生した場合、1 住戸を超えて延焼する可 能性は少ないことが確認できる。建物用途上、住戸ごとの間仕切壁 が存在し、1 住戸ごとの防火区画による火災扡大抑止効果が働いて いることを示している。「木質系」では、焼損床面積 $1 \mathrm{~m}^{2}$ 以下が約 60\%である。「非木質系」のような燃え止まる特徴は見られず、1 住 戸を超えて延焼する場合、焼損床面積は拡大しやすくなることが確 認できる。火災件数が非常に多いが、戸数の多さとともに、台所や 電熱器など火元となりやすい简所が多く、また、滞在者数が少なく、 広く目が行き届かないこともその原因と考えられる。

(3) 物品販売店舗等（図 4)

いずれの建築構造も、焼損床面積の分布特性は「事務所」に類似 しているが、焼損床面積が小さく収まる割合が高く、最大焼損床面 積が大きくなる。「非木質系」では焼損床面積 $1 \mathrm{~m}^{2}$ 以下が約 $80 \%$ 、 $10 \mathrm{~m}^{2}$ 以下が約 $85 \%$ であり、100 $\mathrm{m}^{2}$ 以下が約 $95 \%$ である。建物用途上、 可燃物量は非常に多く、かつ連続しており燃え拡がりやすい特徵を 持つが、火災の初期段階での発見や、初期消火が成功していること 
が推測される。しかし、最大焼損床面積までは緩やかに累積相対度 数が上昇し、可燃物の連続性や防火区画あたりの床面積が大きいこ とが、この原因と考えられる。「木質系」では、焼損床面積 $1 \mathrm{~m}^{2}$ 以下 が約 $50 \% 、 10 \mathrm{~m}^{2}$ 以下が約 $60 \% 、 100 \mathrm{~m}^{2}$ 以下が約 $80 \%$ であり、「非木 質系」に比べて火災が桩大しやすい傾向がある。

(4) 病院等 (図 5)

建築構造による焼損床面積の分布特性の差が最も大きい。「非木質 系」では、焼損床面積 $1 \mathrm{~m}^{2}$ 以下が約 $90 \% 、 10 \mathrm{~m}^{2}$ 以下は約 $95 \%$ であ り、多くの火災が初期に消火されることが示されている。建物用途 上、建築計画的に小さい部屋に区画されやすいこと、また、防火上 主要な間仕切壁の設置や消防用設備等の設置が、焼損床面積桩大一 の抑止効果があることを示している。「木質系」は焼損床面積 $1 \mathrm{~m}^{2}$ 以 下が約 $50 \% 、 10 \mathrm{~m}^{2}$ 以下は約 $60 \%$ であり、「非木質系」に比べて火災 時の安全性は大きく劣る。空閒の大きさが「非木質系」と同様でも、 各部材が木質系であることにより、燃え抗がりやすいものとなって いることが示されている。

（5）工場等 (図 6)

建築構造の差が、他用途に比べて、焼損床面積が大きい範囲では 少なく、累積相対度数約 $95 \%$ の焼損床面積もほぼ同様（約 $500 \mathrm{~m}^{2}$ ) である。いずれのグラフも類似形状で、焼損床面積の拡大傾向が同 様である。空間が一体的であるという特性が焼損床面積の分布傾向 に影響していると考えられる。「非木質系」で焼損床面積 $1 \mathrm{~m}^{2}$ 以下と なる割合は、分析した 5 防火対象物のなかで最も低く約 70\%、「木 質系」は約 40\%である。

\section{2 建物用途間の比較}

「共同住宅等」は「非木質系」で焼損床面積約 $100 \mathrm{~m}^{2}$ で累積相対 度数が約 $100 \%$ で、これ以降のプロットは水平となるが、同用途の 「木質系」と他の用途ではこの傾向は見られず、概ね類似である。

「非木質系」では、「病院等」のプロットが最も上側に位置し、出 火した場合、最も燃え拡がりにくい。焼損床面積 $1 \mathrm{~m}^{2}$ 以下の場合は 「事務所」「工場等」がほぼ同じく約 $40 \%$ であるが、「工場等」のほ うが緩やかに $100 \%$ まで到達し、「工場等」が最も火災桩大しやすい。

「木質系」は、「共同住宅等」のプロットが最も上側で、小規模な 火災に収まる傾向だが、累積相対度数 $100 \%$ 近くで焼損床面積は拡 大する場合も多く、「病院等」が最も小さい焼損床面積で収まる。

\section{5 累皘相対度数の代表値 $\alpha 、 \beta$ の提案}

\section{1 代表値 $\alpha 、 \beta$ 考え方}

4 章で整理した焼損床面積の累積相対度数分布は、焼損床面積の 拡大傾向と、ぼや程度に収まる火災の割合の全体像を概観するため には有効な手法であり、ある焼損床面積に収まる建物の割合などを 知るために有効である注7)。本章ではこれを発展させ、建物用途、 建築構造、日常管理、消防用設備等の設置状況などが被害状況（焼 損床面積）に与える影響を定量化する方法の一つとして、上記のグ ラフに近似式を与える方法を提案する。この利点は、近似式の傾き （ $\alpha$ ）で焼損床面積の増加傾向、切片（ $\beta$ ） 法焼損床面積 $1 \mathrm{~m}^{2}$ の きになり注8)、ぼや程度に収まる割合が把握できることである。

回帰式は簡潔な表現であること(係数や変数が少ない)を重視し、 累積相対度数グラフとの適応状況も考虑し、対数回㷌（ $\mathrm{y}=\alpha \operatorname{Ln}(\mathrm{x})$ $+\beta$ ) とした。図 7 に示す方法で注9)、図 2〜図 6 の回帰式を求めた

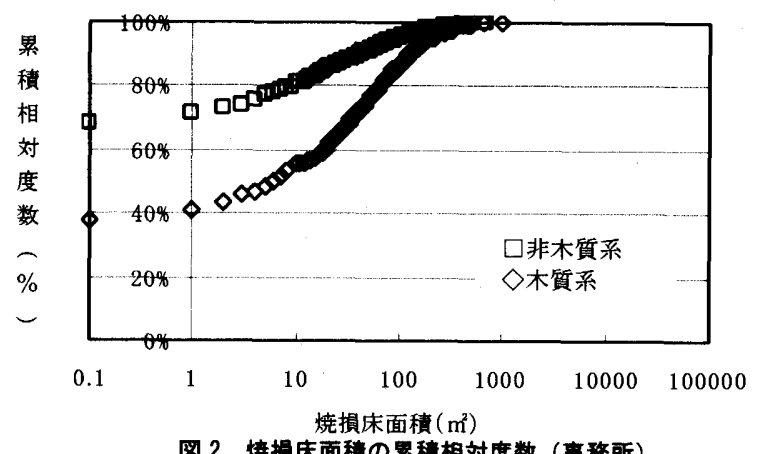

图 2 焼損床面樻の累積相対度数（事務所）

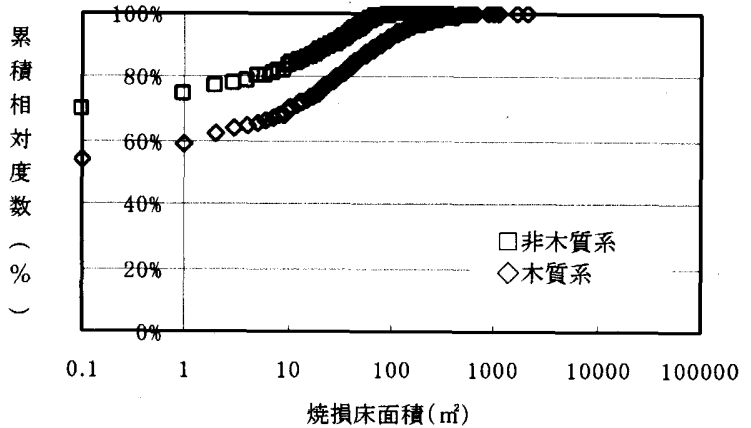

図 3 燒椇床面稘の累稳相対度数（共同住宅等）

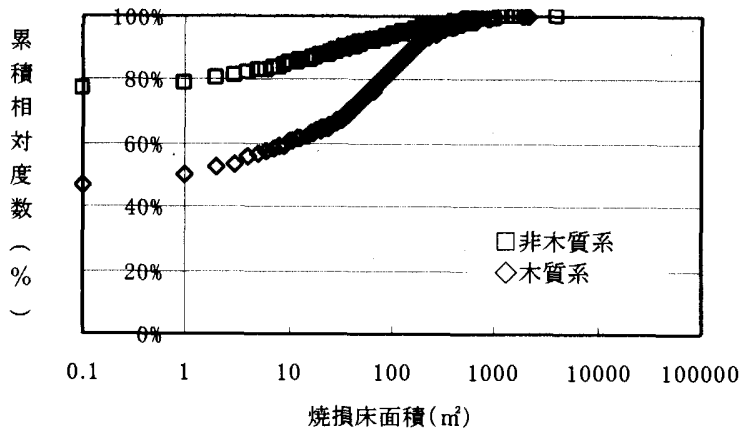

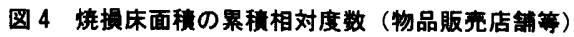

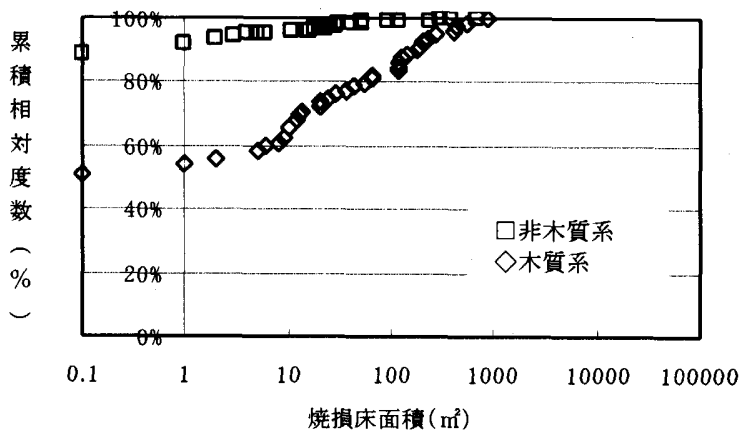

图 5 焼損床面穗の累稳相対度数（病院等）

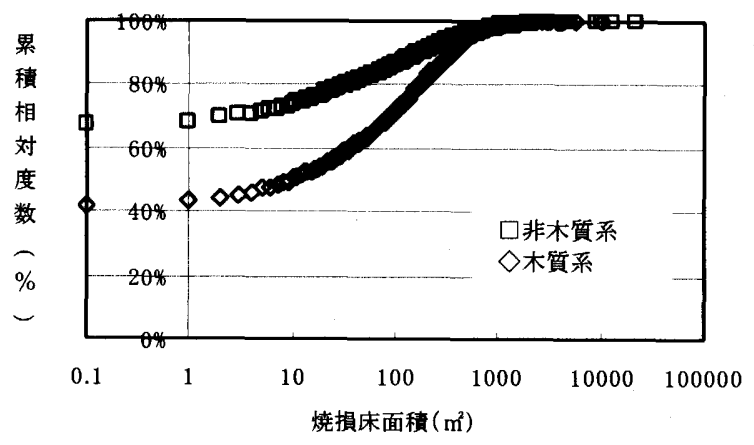

图 6 焼損床面稳の果稳相対度数（工鸤等） 
結果を表 3 に示す。

\section{2 建物用途ことと烧損床面㮴の傾向}

表 1 に示寸防火対象物すべての建築構造別の対数回㷌を求めた。 概ね決定係数は 0.8 以上であり、対数回㷌がよく適合している。

回帰式の係数 $\alpha$ と係数 $\beta$ の值を、X軸、Y軸の值として防火対象 物ごと・建築棈造ごとにプロットしたものが図 8 (「木質系」)・図 9 (「非木質系」) である（プロット横の数字は表 1 を参照)。

建築構造で顕著な違いがあり、「木質系」は係数 $\alpha$ 、係数 $\beta$ ともに 広く分布するが、「非木質系」は数種の防火対象物を除き、係数 $\beta$ が 大きく俰数 $\alpha$ が小さい領域に集中する。「非木質系」の耐火性能の高 さが焼損床面樌の拡大を抑止する効果を実際の火災データを用いて 確認できた。図 8、図 9 の各プロットの保数 $\alpha$ と係数 $\beta$ の相関係数 は、 -0.96 (「木質系」)、- 0.87 (「非木質系」) であり注 10 )、係数 $\alpha$ や倸 数 $\beta$ が同一である場合、用途間の焼損床面樌分布の差は建築構造に よる差はほとんどない。

広い空間を必要とする「合庫」(23 番) は、いずれの建築構造も 最も下側（係数 $\beta$ の值が小さい）に位置するが、「非木質系」は係数

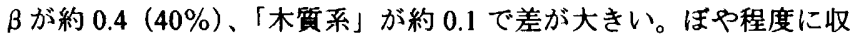

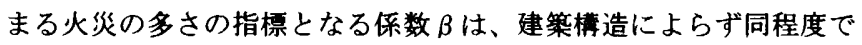
あるのが本来の姿と考えられ、初期消火や初期展炎防止のための消 防用設備等により、抑止効果を高める余地があることを示している。 小さい単位空間を必要とする「病院等」(10 番)、「社会福祉施設 等」(11 番)、「幼稚園等」(12 番) などのプロットは「木啠系」非 木質系」ともに上側（係数 $\beta$ の值が大きい）に位置し、いずれの建 筑構造においても、区画小単位化の損害抑止効果と法規制による効 果があることを示している。また、「木質系」では「共同住宅等」(9 番）も $\beta$ の值が大きく、火炎に弱い構造であっても小区画化が効果 があることを示している。

「文化財」（32 番）と「神社・寺院等」（18 番）は同じ「木質系」 で建築形態も類似が多いが、保数 $\beta$ がそれぞれ 0.60 と 0.20 で差が 大きい。建築棈造以外の防火対策の差により生じたと考えられる。

「料理店等」(5 番)、「共同住宅等」(9番) などの俰数 $\beta$ の值は建 築構造による差が少なく、建勧構造による耐火性能の差を、建策構 造以外の対策で高めていると考えられる。

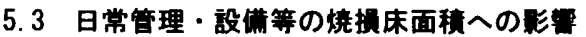

5.2 では、建物の火災損害として焼損床面積の特性を、建物用途 ごとに検討した。本節では、「非木質系」の建物について、日常管理 等の状況と消防用設備等の設置状況が建物の焼損床面稓に与える影 響を分析する。方法は 5.2 と同様である。ここでは、火災報告の記 載項目のうち、火災拡大抑止に影響を与える日常管理や消防用設備 等の状況として、表 4 に示す項目について検討した。これらに関し て、法規上設置など要しない場合は「非該当」に分類されるが、「非 該当」の少ない項目は、「防火管理者の選任」「消防計画書の作成」 「消火訓練の実施」「消火器具の設置」「屋内消火栓の設置」「自動火 災報知設備の設置」であった。また、各項目において「選任」等の 有無で項目間の相関係数を計算したところ、「防火管理者」「消防計 画書」の相関が非常に強く、これらは「防火管理者」で代表できる ものと考えた。また、「消火器具」は非常に多くの建物で設置されて おり、また使用されや寸い設備であるため、火災拡大に与える影響 の差が少ないと考えられる。したがって、本章では、日常管理とし

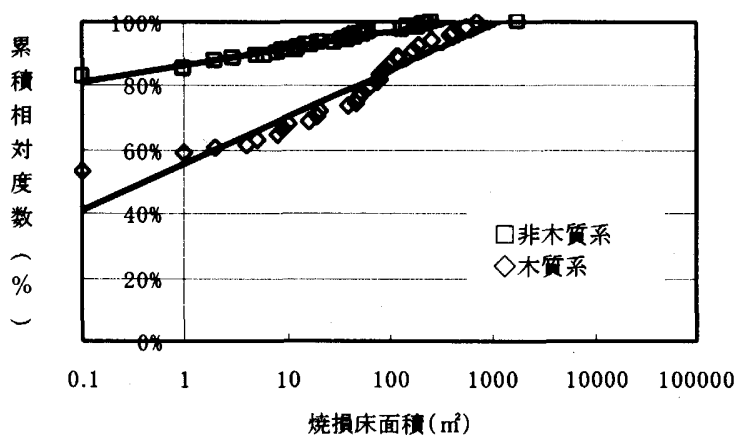

図 7 累積相対度数分布と回㷌式の関保 (注7)

表 3 回带式例

\begin{tabular}{|c|c|c|c|}
\hline & 木質系 & 非木哲系 \\
\hline (05)ロ & 共同住宅等 & $\begin{array}{l}y=0.07 \operatorname{Ln}(x)+0.59 \\
R^{2}=0.93\end{array}$ & $\begin{array}{l}\mathrm{y}=0.05 \operatorname{Ln}(\mathrm{x})+0.74 \\
\mathrm{R}^{2}=0.90\end{array}$ \\
\hline (06)イ & 病院等 & $\begin{array}{l}y=0.07 \operatorname{Ln}(x)+0.52 \\
\mathrm{R}^{2}=0.94\end{array}$ & $\begin{array}{l}y=0.01 \operatorname{Ln}(x)+0.93 \\
R^{2}=0.94\end{array}$ \\
\hline (12)イ & 工場·作業場 & $\begin{array}{l}y=0.10 \operatorname{Ln}(x)+0.27 \\
R^{2}=0.92\end{array}$ & $\begin{array}{l}y=0.05 \operatorname{Ln}(x)+0.66 \\
R^{2}=0.93\end{array}$ \\
\hline (04) & 物品肘克店舖等 & $\begin{array}{l}y=0.09 \operatorname{Ln}(x)+0.41 \\
R^{2}=0.92\end{array}$ & $\begin{array}{l}y=0.03 \operatorname{Ln}(x)+0.79 \\
R^{2}=0.96\end{array}$ \\
\hline (15) & 事務所 & $\begin{array}{l}\mathrm{y}=0.11 \operatorname{Ln}(\mathrm{x})+0.33 \\
\mathrm{R}^{2}=0.93\end{array}$ & $\begin{array}{l}\mathrm{y}=0.05 \operatorname{Ln}(\mathrm{x})+0.71 \\
\mathrm{R}^{2}=0.96\end{array}$ \\
\hline
\end{tabular}

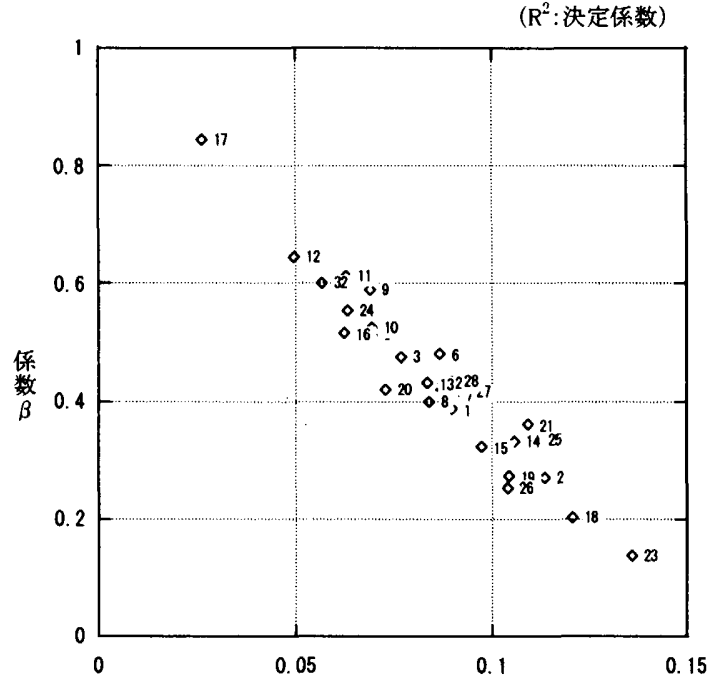

㐿数 $\alpha$

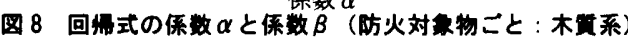

プロット横の数字は表 1 参照

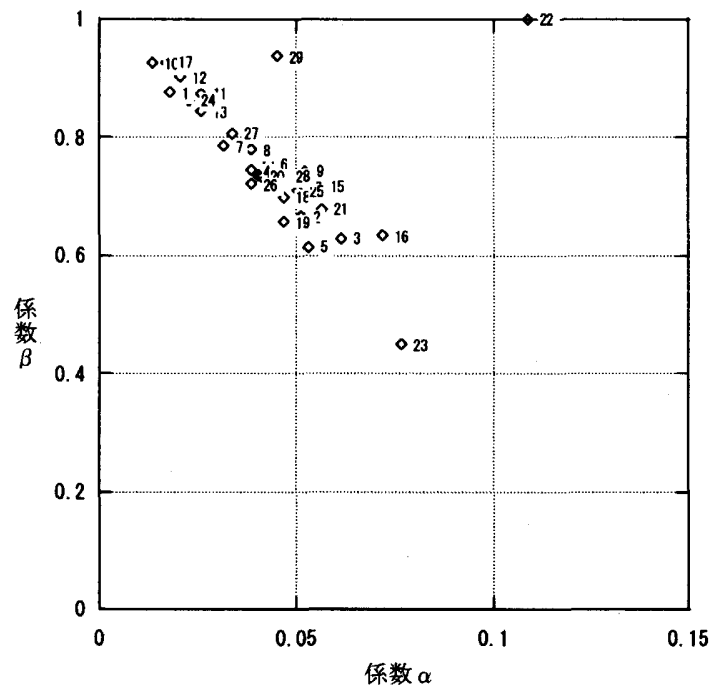

图 9 回雨式の係数 $\alpha$ と係数 $\beta$ （防火対象物ごと：非木筫系） プロット横の数字は表 1 参照 
て「防火管理者の選任」「消 火訓練の実施」、消防用設備 等として「屋内消火栓の設 置」「自動火災報知設備の設 置」を代表させた。また、 各項目に関して火災報告に 記載される分類は表 4 の 「火㷋報告」欄によるが、 選任の有無・設置の有無・ 使用の有無などを明確にす るため、「本研究」欄のよう に選択肢を集約して分析し た。

係数 $\alpha$ と倸数 $\beta$ の值をそ れぞれX軸、Y軸の值とし てグラフ上にプロットした ものが、事務所」(図 10)、 「共同住宅等」(図 11)、「物 表 4 日常管理・設借等の状況の顷目

\begin{tabular}{|c|c|c|c|c|c|}
\hline \multirow{2}{*}{ 項目 } & \multicolumn{2}{|r|}{ 分類 } & \multirow{2}{*}{ 項目 } & \multicolumn{2}{|r|}{ 分類 } \\
\hline & 本研究 & 火災報告 & & 本研究 & 火災報告 \\
\hline \multirow{5}{*}{$\begin{array}{l}\text { 「防火管理者」 } \\
\text { 選任状況 }\end{array}$} & 非該当 & 非該当 & \multirow{3}{*}{$\begin{array}{l}\text { 「適マーク」 } \\
\text { 交付状況 }\end{array}$} & \multirow{3}{*}{-} & 非該当 \\
\hline & \multirow{3}{*}{ 選任 } & 選任(届出済) & & & 交付あり \\
\hline & & 選任 (未届出) & & & 交付なし \\
\hline & & 一部未選任 & \multirow{7}{*}{$\begin{array}{l}\text { 「防炎物品」 } \\
\text { 使用状況 }\end{array}$} & \multirow{7}{*}{-} & 非該当 \\
\hline & 未選任 & 末選任 & & & 義務あり(未使用) \\
\hline \multirow{7}{*}{$\begin{array}{l}\text { 「消防計画」 } \\
\text { 作成状況 }\end{array}$} & \multirow{7}{*}{-} & 非該当 & & & 義務あり(一部使用) \\
\hline & & 作成（選任·内容適正·届出済） & & & 義務あり (全部使用) \\
\hline & & 作成（選任・内容適正・末届出） & & & 義務なし(一部使用) \\
\hline & & 作成（選任·内容不適正・届出済） & & & 義務なし (全部使用) \\
\hline & & 作成 (選任·内容不適正・未届出) & & & 義務あり(不明) \\
\hline & & 末作成（権原複数·一部未作成） & \multirow{14}{*}{$\begin{array}{l}\text { 消防用設備等の設置状況 } \\
\text { 「消火器具」 } \\
\text { 「屋内消火栓設備」 } \\
\text { 「スプリクラー設備」 } \\
\text { 「水噴蝚設備等」 } \\
\text { 「屋外消火栓設備」 } \\
\text { 「動力消防ポンフ設備」 } \\
\text { 「自動火災報知設備」 } \\
\text { 「漏電火災警報器」 } \\
\text { 「非常警報器具·設備」 } \\
\text { 「消防用水」 } \\
\text { 「連結送水管」 } \\
\text { 「連結散水設備」 }\end{array}$} & 非該当 & 非該当 \\
\hline & & 末作成(選任済) & & \multirow{4}{*}{ 使用 } & 政令による設置対象 \\
\hline \multirow{8}{*}{\begin{tabular}{|l} 
「消火訓練」 \\
実施状況
\end{tabular}} & 非該当 & 非該当 & & & (設圈·使用) \\
\hline & \multirow{6}{*}{ 実施 } & 実施 (2回以上) & & & 政令による設贯対象外 \\
\hline & & 実施(1回のみ) & & & (設置·使用) \\
\hline & & 実施(管理権原複数) & & \multirow{4}{*}{ 使用せず } & 政令による設置対象 \\
\hline & & 実施（権原複数・1回のみ） & & & （設置·使用せず） \\
\hline & & 実施 (権原複数・一部含まない) & & & 政令による設贯対象外 \\
\hline & & 実施(1回のみ・権原複数・一部含まない) & & & (設睓·使用せず) \\
\hline & 実施せず & 全く実施していない & & \multirow{5}{*}{ 設置せず } & 政令による設貫対象 \\
\hline \multirow{4}{*}{$\begin{array}{l}\text { 「共同防火管理」 } \\
\text { 実施状況 }\end{array}$} & \multirow{4}{*}{ - } & 非該当 & & & (設冨せず) \\
\hline & & 協議事項制定·共同防炎管理実施 & & & \\
\hline & & 協議事項制定·共同防火管理一部不備 & & & \\
\hline & & 全く行われていない & & & \\
\hline
\end{tabular}
品販売店舗等」(図 12)、「病院等」（図 13）、「工場等」(図 14）であ る。また、それぞれにおいて、「防火管理者の選任」(a)、「消火訓練 の実施」(b)、「屋内消火栓の設置」(c)、「自動火災報知設備の設置」 （d）で示している。これらの図で、設備等の状況によらず「非木質 系」全体としてのプロット（×印）を以下では「基準位置」とした。

\section{（1）防火管理者の選任}

全体的な傾向は、「共同住宅等」は $\alpha 、 \beta$ ともに非常に狭い範囲で、 「工場等」も同様である。「事務所」は $\alpha 、 \beta$ ともに広い範囲である。 「病院等」「物品販売店舖等」は中間の傾向である。

「事務所」は、「非該当」は $\beta$ が 0.59 と最も低く、その他は約 0.9 と高い。「選任」と「未選任」では $\alpha 、 \beta$ ともに差がほとんど無いが、 「該当」と「非該当」では、「該当」の $\beta$ が 0.28 高い。防火管理者 の選任要件は滞在者人数であり、「事務所」は就業時間内は常に一定 以上の人数が滞在しているため、防火管理者の選任の有無よりも常 に人が滞在していることの重要性が示されていると考えられる。

「共同住宅等」は、 $\beta$ はいずれの場合もほぼ同様で約 0.73 である。 また $\alpha$ もほぼ同様で約 0.05 である。「共同住宅等」は各住戸ごと独 立した性格が非常に強いため、防火管理者の選任有無の影響は非常 に低いことが考えられる。

「物品販売店舖等」は、「選任」は $\beta$ が 0.86 と最も高く、「未選任」 が 0.62 と最も低い。「該当」は 0.81 と「非該当」は 0.71 であり、建 物規模よりも選任の有無の影響が大きい。「物品販壳店舖等」は床面 積も広く、従業員一人あたりの床面積も広いため、防火管理者を選 任し、従業員の防火意識などの啓蒙を行うことが重要であることを 示している。

「病院等」は、「非該当」は $\beta$ が 0.78 と最も小さく、その他は約 0.95 と高い。「病院等」は各病室や執務室など独立した小規模な室 が多いことは「共同住宅等」と類似であるが、「病院等」の各室の使 用状況は一体となっている場合が多く、また、火災発見や初期消火 は従業員に依存することになり、防火管理者を選任して管理を統括 することが重要であることを示している。

「工場等」は、「該当」「選任」は $\beta$ が 0.76、「未選任」が 0.70、「非
該当」が 0.59 である。「該当」と「非該当」の差が大きいことは、 「工場等」は面積が広く、作業エリアの構成も複雑であるため、あ る程度の人数の滞在が重要であること、また、「選任」と「未選任」 の差もあることから、防火管理者による従業員の管理の必要性も示 されている。

\section{（2）消火訓練の実施}

全体的な傾向は、防火管理者の選任状況と類似である。

「事務所」は、「非該当」は $\beta$ が 0.59 と最も低く、「実施」が 0.91 と最も大きい。 $\beta$ は、全体平均值 0.71 から幅広く分布している。訓 練を実施した場合は、しない場合に比べて拡大被害を示す $\alpha$ が 0.05 程度小さい。「非該当」の建物グループでは、 $\beta$ が他の区分に比べて 0.3 程度小さくなり、拡大被害発生の危険が高い。建物の規模など で「該当」「非該当」を定めている現行の規定の弱点が伺われる。 $\alpha$ も、「非該当」の值が他の区分に比べて非常に大きいが、これは防火 区画の大きさに制限があることによるものと推察できる。

「共同住宅等」は、 $\beta$ の全体平均は 0.74 であり、「該当、非該当」、 「実施、実施せず」の各区分での平均 $\beta$ との差もあまり大きくない。 しかし、「該当、実施」の区分の方が 1 ～2\%程度大きな值を示して おり、これらの区分は被害を抑える効果があるといえる。一方、い ずれの区分の $\alpha$ も 0.05 0.06の範囲にあり、全体平均からの差も小 さい。空間規模が概ね $100 \mathrm{~m}^{2}$ 以下と小さく区分されていることや、 仮に消火訓練が必要で訓練を実施している建物であっても、実際に 訓練の経験者はすべての住宅居住者ではないことなどと推察する。

「物品販売店舗等」の $\alpha$ は $0.03 、 \beta$ は 0.8 程度である。 $\beta$ に着目 すると「該当」と「非該当」の差は 0.1 、「実施」と「実施せず」の 差では 0.2 である。消火訓練を必要とする建物とすることや、消火 訓練を実施させることが $\beta$ を大きくすることに大きな意味を持つこ とがわかる。一方 $\alpha$ は、非該当」や「寒施せず」の 2 区分が大きな 值を示す。この用途を含めて、本章で分析している用途では、一般 的に空間の大きさが防火区画の規模などの規制により火炎発生区画 の大きさに限度があることに、これらの原因は帰着すると推察する。

「病院等」は、過去の火災事故を教訓として火災安全対策を強化・ 


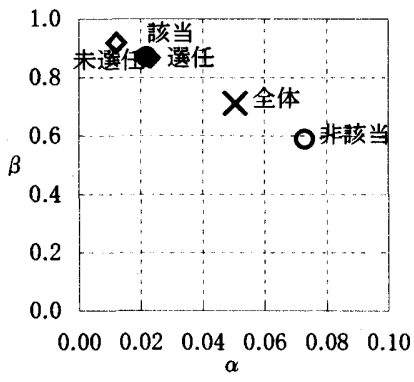

(a) 防火管理者

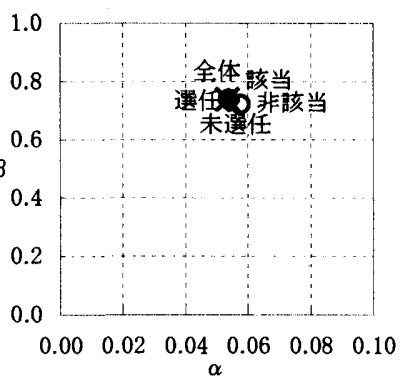

（a）防火管理者

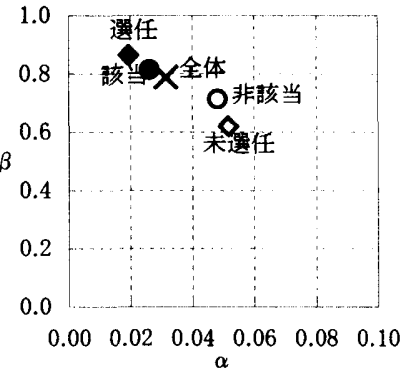

（a）防火管理者

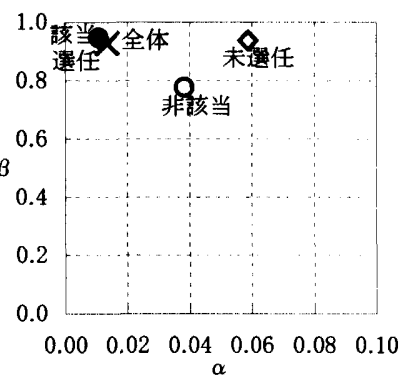

（a）防火管理者

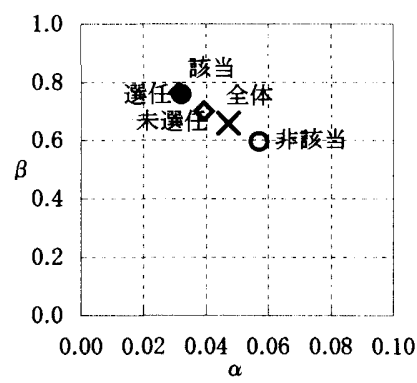

（a）防火管理者
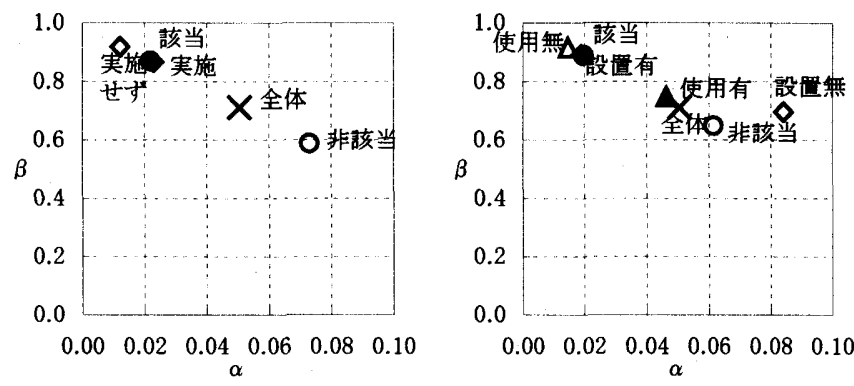

(b) 消火訓練

\section{因 10}
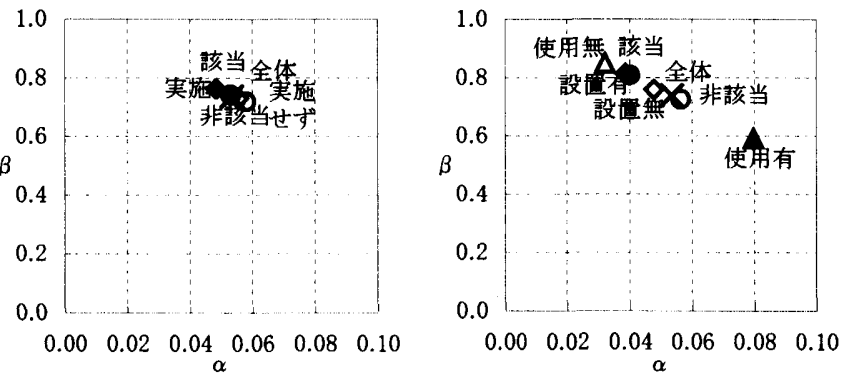

(b) 消火剖練

(c) 屋内消火栓

因 11 共同住宅第
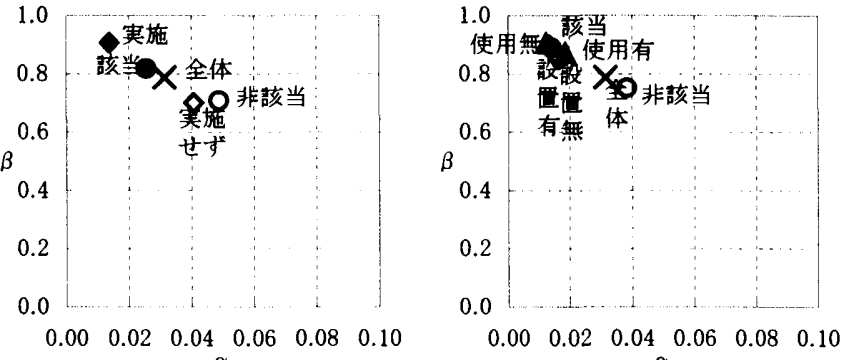

（b）消火訓練

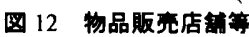

(c) 屋内消火栓
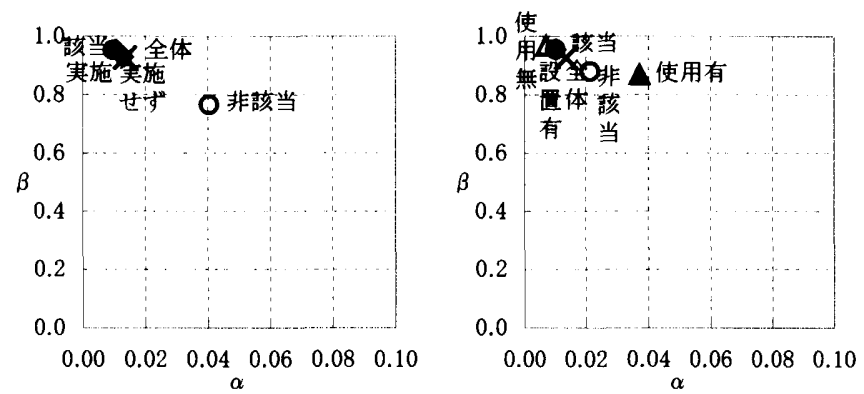

（b）消火訓練

\section{图 13 病院等}

（c）屋内消火栓

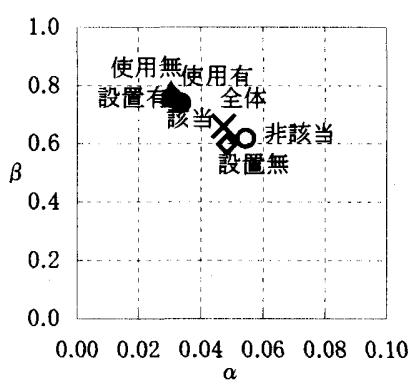

(c) 屋内消火栓

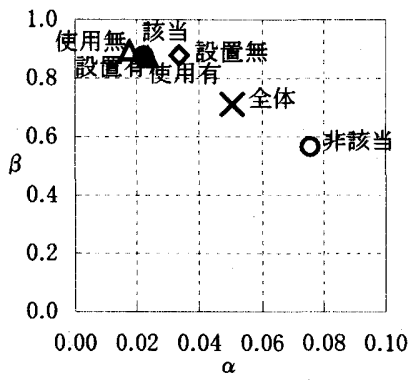

（d）自動火災報知設備

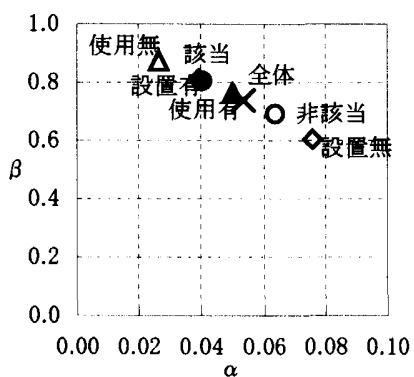

（d）自動火災報知設備

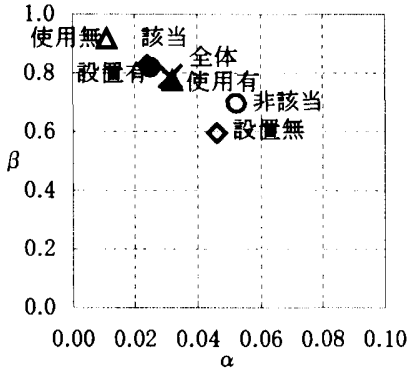

（d）自動火災報知龍備

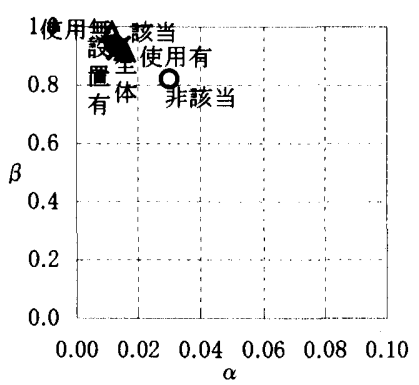

（d）自動火災報知設備

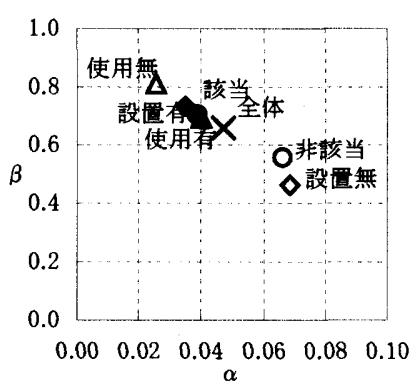

（d）自動火災報知設備 
遡及した用途である。その効果が現われ、全体平均の $\beta$ は 0.93 と他 用途に比べて大きい。ここで「非該当」を除いたそれぞれの $\beta$ は全 体平均よりも大きな値を示し、安全側にある。しかし、「非該当」の $\beta$ は 0.76 (「共同住宅等」の全体平均 $\beta$ と同程度）を示すことに着 目すると、「非該当」の対象であることで、関係者の防火管理意識の 低下が表われている。一方、「非該当」の $\alpha$ は 0.04 とそれ以外の值 の 0.01 に比べて大きな值を示す。これは「該当」「非該当」いずれ も用途として要求される単位空間の規模(病室の大きさは概ね一定) に大差がなく、それが焼け止まりとなるため、 $\beta$ の小い「非該当」 では、結果として $\alpha$ が大きくなると考えられる。「病院等」では $\beta$ が 重要な管理尺度といえる。

「工場等」は、全体平均の $\alpha$ は $0.03 、 \beta$ は 0.66 である。「非該当」 の割合が多いためか、全体の平均值は「非該当」に近づいている。 「該当」や訓練の有無の $\beta$ は 0.75 近辺に散布している。 $\alpha$ は、「該 当」「実施」が 0.03 、「非該当」「実施せず」が 0.06 程度である。

\section{（3）屋内消火栓の設置}

全体的な傾向は、「事務所」「共同住宅等」は $\alpha 、 \beta$ ともに広い範 囲に拡がり、「病院等」「工場等」は狭い範囲であり、「物品販売店舗 等」はそれらの中間の傾向を持つ。

「事務所」は、「非該当」は $\beta$ が 0.65 と最も低く、次いで「設置 無」の 0.69 である。これらは「設置有」の 0.89 と差が大きい。「設 置無」は設置義務があるが設置していない建物群であり、適切な消 火設備を設置することの重要性を示している。また、設置していな い場合でも、火災の桩大傾向を示す $\alpha$ が、「設置無」のほうが「非該 当」より大きく、「非該当」は小規模であるがゆえの小区画化により 火㷋桩大が抑えられている可能性がある。「使用有」と「使用無」で は、「使用有」のほうが $\beta$ が大きい。「事務所」では「屋内消火栓」 を設置している場合、「消火器具」も設置しているため、「屋内消火 栓」を使用する以前に消火できたケースと推測される。「屋内消火栓」 は使用までの準備に時間がかかり、操作に習熟していないことも推 測され、ごく小規模な焼損範囲に収める場合は、「屋内消火栓」の効 果は低いことを示している。

「共同住宅等」は、「使用有」の $\beta$ が最も低い。これは、「共同住 宅等」では住戸内に「屋内消火栓」は設置されてなく、住戸から出 火した場合の初期火災時での使用が困難であること、住戸内で出火 し消火器具による初期消火が達成できなかった場合には、一住戸内 広範に搪大寸る可能性があることによると考えられる。「非該当」と 「設置無」はいずれも設置していない建物であり、また、火災の状 況も類似しており、「屋内消火栓」の効果は、建物規模（「非該当」 は建物規模が小さい)に関わらずほぼ同じであることが推測できる。

「物品販売店舗等」は、「事務所」「共同住宅等」に比べて、ぼや 等狭い範囲で火災が収まる傾向（ $\beta$ の值）が大きく、拡大しにくい 傾向（ $\alpha$ の値）がある。「非該当」が最も $\beta$ が小さく、「使用有」は $\beta$ が大きく、「使用無」と「使用有」の差が小さい。「物品販売店舗 等」では、比較的初期の火災の時点で「屋内消火栓」が使用されて 火災搪大抑止への有効性が示されている。

「病院等」は、各プロットが他の用途に比べて最も左上に集まり、 「屋内消火栓」の設置や使用状況の違いで火災拉大に影響を与える 傾向はない。「使用有」と「非該当」の $\beta$ はほぼ同じであるが、「使 用有」は $\alpha$ が大きい。これは、ぼや程度に収まる割合はほぼ同じで
あるが、「屋内消火栓」を使用したことにより、火災拡大が抑えられ たことを示している。また、「使用無」の場合は、 $\beta$ が 0.97 と非常 に高く、「屋内消火栓」使用まで至らない規模の火災の場合、初期消 火が成功している場合が非常に高いことを示している。

「工場等」は、大きく2つの群にプロットが分けられる。「非該当」 「設置無」は $\beta$ が小さく、「使用有」「使用無」は $\beta$ が大きい。前者 は、火炎が発生した場所でも使用されていない場合であり、使用有」 の $\beta$ が大きいことは、「工場等」の火災では「屋内消火栓」の設置は 火災搪大に非常に効果が高いことを示している。

（4）自動火災報知設備の設置

全体的な傾向は、「病院等」は $\alpha 、 \beta$ ともに狭い範囲であり、その 他の用途は広く分布している。

「事務所」は、「非該当」は $\beta$ が 0.56 と最も小さく、その他は 0.87 前後であり、差が大きい。「非該当」は設置義務の無い小規模建物で あり、延床面積の大小による設置規定の弊害が現われている。

「共同住宅等」は、「設置無」の $\beta$ が 0.60 と最も小さく、次いで 「非該当」の 0.69 である。自動火災報知設備は火災初期の迅速な対 応に重要であり、ここでも延床面積の大小で設膡規定があることの 弊害が現われている。最も大きい值は「使用無」の 0.87 であるが、 これは、自動火災報知設備による感知以前に居住者が発見し消火で きたものと考えられる。「使用有」は「設置無」よりも $\beta$ が 0.16 高 く、仮に、「設置無」の建物に設置されていた場合、小規模火災で収 まった可能性が高いことが推測できる。

「物品販売店舗等」は、 $\beta$ が「設置無」(0.32)、「非該当」(0.37) と低く、設置していないことの問題点が現われている。「使用」の $\beta$ は「設置無」の約 2 倍大きく、設置されていれば火災拡大は防ぐこ とができた可能性がある。火災の拡大しやすさを示す $\alpha$ は、非該当」 (0.10)、「設置無」（0.07）であり、 $\beta$ はほぼ同じである。これは、 「設置無」のほうが焼損床面積が拡大しやすいことを示しており、 設置義務がある延床面積の大きい建物の場合、設置していないこと の危険性が現われている。

「病院等」は、いずれのプロットも他の用途に比べて最も左上に 集まっている。「非該当」の $\beta$ が最も小さく、病院などのように延床 面積が広く、入院患者の対応など複雑な業務を必要とする用途では、 入院患者などの安全性も考えると、建物規模で設備の設置の有無を 規定することは、大いに問題があるといえる。

「工場等」は、 $\beta$ は「非該当」(0.20) と小さく、「使用」(0.52) と大きい。建物規模による設置義務の有無の問題点が示されている。 $\alpha$ は「非該当」(0.12)、「設置無」(0.09) であり、これらの $\beta$ は近 い値である。「物品販売店舗等」と同様に、設置義務のある大規模な 建物で設置していないことの問題点が現われている。

\section{7 全体の考察}

建築物の火災損害を示す指標として焼損床面積を使用した。焼損 床面積の拡大は様々な要因の影響を受けるが、その傾向は防火対象 物の種類と建筑構造で大きく異なることを示した。

損害拡大を抑止するためには、建築的な防火対策の一つである小 区画化が有効であることが確認できた。小区画化ができない用途で は、その他の防火対策（日常管理や消防用設備等）によって損害拡 大を防ぐことが考えられる。 
次いで、日常管理や消防設備等が焼損床面積の傾向に与える影響 を分析するために、焼損床面積の累積相対度数グラフを対数回帰し た近似式の傾き（ $\alpha)$ と切片（ $\beta$ ）を代表值として提案した。「選任」 「使用」等の場合に、必ずしも $\beta$ の值が小さくなるわけではなく、 「設置無」や「使用無」とあわせて比較検討し、当該用途建物で、 その設備等の有効性があるか否かを判断することが重要である。

また、「非該当（法令の設置対象外で設㯰なし)」については、法 的に設置や使用の義務がない建物グループも設置の必要がない訳で はなく、設置により損害を減らすことができるものと考えられる。

最も身近で火災件数も多い「共同住宅等」は、他の用途に比べ、 「非木質系」のほぼ全ての火災事例の最大焼損床面積が、概ね 1 住 戸である特徵を持つ。これは、防火区画の重要性とともに、防火区 画が有効に働くこと（屝等が開放されていない）の重要性も示して おり、防火戸の閉鎖障害防止なども含めた日常管理の徹底が火災拡 大抑止に有効であることを示している。

\section{8 まとめ}

防火対象物区分、建築構造、日常管理や消防用設備等の状況別に 作成した焼損床面積の累積相対度数分布を、回帰式の係数を用いて 比較することにより、火災の拡大や抑制に影響する項目と影響の大 きさを分析した。本研究の結果は、建物用途、建築構造、日常管理 の状況、消防用設備等の状況がわかれば、当該建物の火災拡大傾向 やぼや程度で収まる割合の概要を简易に把握できる。これは $\alpha$ と $\beta$ という 2 つの指標で示すことができ、当該建物に関わる様々な分野 の人の共通尺度として理解されやすいものであり、また、既存建物 の火災安全性把握だけでなく設計段階でその建物に必要とされる日 常管理や消防用設備等の検討も可能であり、火災安全性を事前に把 握するツールとして提案できる。

\section{解辞}

本研究の取りかかりとなった分析は、鈴木恵子氏（独立行政法人消防研究 所）との共同研究によるものであり、ここに感謝の意を表します。

注1）火災報告：消防法第 24 条、消防組織法第 22 条による。

注2) 入手データは 1995 年〜2002 年だが、1995 年は阪神淡路大震災のデー タも入っており、日常災害としての火災リスクを検討する本論文の正 確性を損なう可能性があるため、1996 年〜2002 年とした。

注3）防災行政研究会「火災報告取扱要領ハンドブック」に基づいて分類し ている。

注4) 回㷌式については、直線、対数、指数、べき乗、分数、ロジスティッ ク、ジンペルク、二次関数について決定係数を調べたが、対数とべき 乗がほぼ同様の最も高い值が得られた（表 3 に示すように 0.90 から 0.96)。最終的には、本研究の主要対象である非木質系建物の場合に決 定係数が高かった対数を採用した。

注5）焼損床面積（横軸）は対数表示したため、焼損床面積 $0 \mathrm{~m}^{2}$ は $0.1 \mathrm{~m}^{2}$ と 置き換えて図示した。

注6) 火災報告の分類では「その他の建築物」もあるが、耐火性が不明確な ため分析精度への影響を考虑し、本研究では扱わない。

注7）たとえば、焼損床面積 $100 \mathrm{~m}^{2}$ 以下に収まる場合の建物数の割合を知り
たいときなど。

注8)横軸は対数軸となるため。

注9) 図 7 において、上側のグラフは係数 $\beta$ の值が大きく、焼損床面積が小 さく収まる場合が多いことを示している。一方、下側のグラフは、倸 数 $\beta$ の值が小さく、焼損床面積が大きくなる場合が多いことを示す。 回帰式の係数 $\beta(x=1 （ \mathrm{LN}(1)=0)$ のときの y の值）が大きいほど、 焼損床面積が $0 \mathrm{~m}^{2} や 1 \mathrm{~m}^{2}$ などで収まる割合が多いことを示す。回帰式 の係数 $\alpha$ は累積相対度数の増加の程度を意味し、 $\beta$ の值が同一ならば、 值が大きいほど狭い焼損面積で収まりやすいことを示す。

注10) 非木質系では、航空機格納庫」のみ他のプロットと大きく外れており、 火災件数も少ないため相関係数を求める際は除外した。

\section{考文神}

1) 関沢愛：住宅火災の初期拡大危険の分析, 火災,Vol.27, No.6(111), 1997 年

2) 関沢愛 : 木造住宅における火災应大危険の要因分析、日本建築学会論文 報告集，第 284 号，1979 年

3)水野智之：火災統計にみた建物規模別・棈造別火災損害について，日本 建築学会大会学術講演梗概集, A-2 分冊, pp.281-282, 2005

4）鈴木恵子: 火災統計からみた防炎物品の状況と火災による損失に与える 影蠁，日本建策学会大会学術講演梗概集，A-2 分冊，，pp.279-280，2005

5) 村井裕樹・鈴木恵子・栗岡均・志田弘二・佐藤博臣 : 焼損面樌の分布特 性に関する考察一防火対策の火災損害抑止効果に関する統計分析 (その 1), 日本火災学会研究発表会概要集，pp.336-339，2003

6)鈴木恵子・村井裕㰾 - 栗岡均 - 佐藤博臣 - 志田弘二 : 焼損面積一影響寸 る日常管理・消防用設備等の要因分析一防火対策の火災損害抑止効果に 関する統計分析 (その 2), 日本火災学会研究発表会概要集, pp.340-343, 2003

7) 村井裕樹・志田弘二・鈴木恵子・栗岡均・佐藤博臣 : 焼損面積の分布特 性值の提案－防火対策の火炎損害抑止勃果に関する統計分析 その 1 ， 日本建築学会大会学術諈演梗概集, A-2 分冊, pp.199-200, 2003

8) 志田弘二・村井裕檄・鈴木恵子・栗岡均・佐藤博臣 : 焼損面積の分布特 性に影郳する日常管理・消防用設備等の要因分析一防火対策の火災損害 抑止効果に関する統計分析 その 2 , 日本建築学会大会学術講演梗概集, A-2 分冊, pp.201-202, 2003

9)野崎洋之・小林裕: 統計デー夕に基づく火災リスク評価手法について(そ の1）火災リスク評価手法の全体桃成と火災の発生確率, 日本火災学会 研究発表会概要集, pp.350-351, 2004

10）野崎洋之・小林裕: 統計データに基づく火災リスク評価手法について(そ の2）火災リスク曲線の定式化法の提案, 日本火災学会研究発表会概要 集, pp.352-353, 2004

11) 村井裕樹・佐藤博臣・栗岡均・志田弘二：日常管理・消防用設備の充実 度と焼損面積の関保, 日本火災学会研究発表会概要集, pp.118-121, 2005

12）小林裕・野崎洋之:統計デー夕に基づく火災リスク評価手法について（そ の3) 建物規模別の火災リスクの比較, 日本火災学会研究発表会概要集, pp.108-111, 2005 